\title{
キラルネマチック液晶相でのヘリックス状ポリアセチレンの合成
}

\section{赤木和夫 筑波大学物籃工学系}

共役系高分子であるポリアセチレンはシス型あるいは トランス型にかかわ加ず直鎖状平面構造とされている. もし，本来の高導電性を保ったまま，一方向に㸚じれた ヘリックス状あるいはスパイラル状のポリアセチレンが 得られたら, 従来にない電磁的性質や特異な光学的性質 が発現することが期待される. 本研究では, キラルネマ チック液晶を溶媒とする不斉異方性反応場でアセチレン の重合を行い, 高分子鎖挍よびそれらの束であるフィブ リルがヘリカル構造をあつ高導電性のポリアセチレン薄 膜を合成した12 2).

軸性キラルな $R$ 体扔よび $S$ 体のビナフトールにフェ ニルヘキシル系置換基を導入したバイノール誘導体を合 成し，これらをキラルドーパントしてネマチック液晶の 等重量混合系に加え，キラルネマチック $\left(\mathrm{N}^{*}\right)$ 液晶を調 製した，偏光顕微鏡では $\mathrm{N}^{*}$ 相に特有な筋付き光学模様 が観察された. 調製した 2 種類の $N^{*}$ 液晶に所定量の Ziegler-Natta 触媒 $\left[\mathrm{Ti}(O-n-\mathrm{Bu})_{4}-\mathrm{Et}_{3} \mathrm{Al}\right]$ を加えた際も $\mathrm{N}^{*}$ 相が保持されていることを確認した後, この不斉液 晶場でアセチレンの重合を行った。
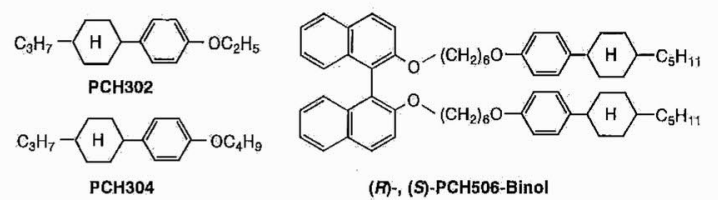

キラルネマチック液晶

$$
\text { スキーム } 1
$$

走查型電子顕微鏡 (SEM) の測定から, 合成したポリ アセチレン薄膜は数本のフィブリルが束となって左巻き あるいは右巻きにらせんを巻いていることがわかった。 フィブリルのらせんの向きは， $R$ 体抢よび $S$ 体の $\mathrm{N}^{*}$ 液 晶の場合，それぞれ左巻き执よび右巻きであり，これは $\mathrm{N}^{*}$ 液晶そのむののらせんの向きと一致した，さらに円 偏光二色性スペクトルを測定すると， $R$ 体抢よび $S$ 体の $\mathrm{N}^{*}$ 液晶を用いた場合, ポリエン主鎖の $\pi \pi^{*}$ 遷移に基づ く吸收領域にそれぞれ正拉よび負の Cotton 效果がみら れ，ポリエン主鎖そのものが左および右方向にねじれて いることが確認された。

大きな旋光度を有したキラルドーパントは強いらせん 誘起力をもち, ヘリカルポリアセチレンのらせん構造に もより大きなねじれをひたらすと考えられる，そこで，

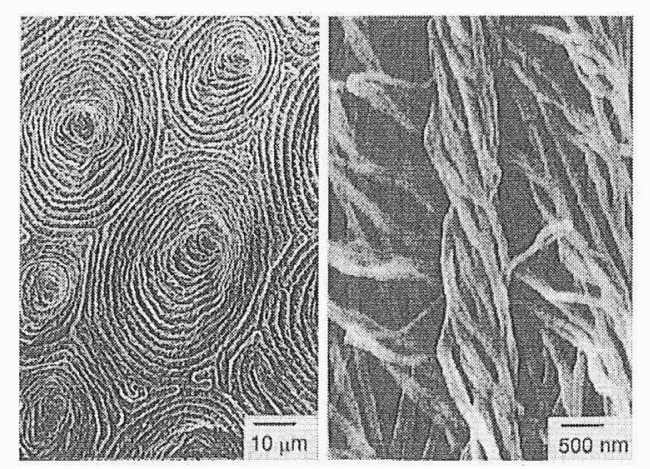

図 1 不斉液晶場で合成したへリカルポリアセチレ ンの走查型電子顕微鏡写真

図 1 に，より大きな旋光度をあつバイノール誘導体から なる $N^{*}$ 液晶 ( $R$ 体) を用いて合成したへリカルポリア セチレンの SEM 写真を示す，不斉異方性反応場でらせ ん構造を有するポリエン鎖が成長し, それらが㠜集し あってらせん状のフィブリルの束を形成している。 さら に，このフィブリルの束は巨視的にスパイル（渦巻き） 状のモルホロジーを形成している様子がわかる，これに より，反応場のらせん方向をそのまま写しとったへリカ ル構造が, 高分子鎖の一次構造加ら高次構造に至るま で，見事な階層性をもって構築されていることが明らか になった。

このへリカルポリアセチレン薄膜は, ヨウ素ドーピン グ後, $1.5 \sim 4.3 \times 10^{3} \mathrm{~S} \mathrm{~cm}^{-1}$ と高い導電性を示すのみな らず，ドーピング処理や熱異性化後むへリカル構造が保 たれることが確認されている。このようなへリカルポリ アセチレンはその高い導電性と特異ならせん構造のた め, 分子ソレノイドとしての電磁気的性質や, 従来にな い光学的二次非線形性を有する新規材料になりうる. 同 時に, キラルネマチック液晶に基づく反応場は, ここで 述べたポリアセチレンの構造規制に留まらず，その他多 くの重合反応や広く化学反応におけるキラル制御にあ利 用できるものと期待される.

\section{文献}

1) K. Akagi, G. Piao, S. Kaneko, K. Sakamaki, H. Shirakawa, M. Kyotani: Science, 282, 1683 (1998)

2) 赤木和夫, 白川英樹：液晶, 2(3), 173 (1998)

(教授, 工博. 専門=導電性高分子, 物質化学) 